\title{
26. ORGANIC GEOCHEMICAL STUDIES OF TWO SAMPLES FROM HOLES 447A AND 448 FROM DEEP SEA DRILLING PROJECT LEG 59
}

\author{
S. C. Brassell and G. Eglinton, Organic Geochemistry Unit, University of Bristol, School of Chemistry, \\ Cantock's Close, Bristol BS8 1TS, England
}

\begin{abstract}
All of the extractable lipids recognized in the two organically lean Deep Sea Drilling Project Leg 59 samples (447A-10-2, 104-120 cm and 448-1-1 70-85 cm) by computerized gas chromatography-mass spectrometry appear to be extraneous contaminants, originating from plasticizers and drilling lubricants. The inability to detect genuine geolipid components demonstrates that the extractable lipids of certain lithologies lie outside the range of current analytical techniques in organic geochemistry. The pipe dope used in DSDP drilling operations was found to contain a complex mixture of diasteranes, steranes, and $17 \alpha \mathrm{H}, 21 \beta \mathrm{H}$-hopanes; hence any assignment of these compounds as components of DSDP sediments must include an evaluation of possible contamination from this source.
\end{abstract}

\section{INTRODUCTION}

The extractable lipid compositions of two Leg 59 samples-447A-10-2 and 448-1-1 (Table 1)-were investigated by gas chromatography (GC) and computerized gas chromatography-mass spectrometry (C-GCMS). A sample of pipe dope was also analyzed to evaluate any effect this frequent shipboard contaminant had on these sediments.

\section{METHODS}

\section{Lipid Extraction and Separation}

The method of extraction and the precautions taken to minimize sample contamination during workup have been reported by Barnes et al. (1979). In anticipation of low quantities of extractable lipids, we subsequently introduced separation procedures that differed from this previous methodology. No saponification step was performed and the total extracts were methylated $\left(\mathrm{BF}_{3} / \mathrm{MeOH}\right)$ prior to thin-layer chromatography (TLC). TLC separation $\left(\mathrm{SiO}_{2}\right.$ gel $\mathrm{G}$ eluted with $\mathrm{CH}_{2} \mathrm{Cl}_{2}$ ) of the total methylated extract afforded four fractions equivalent in $R_{f}$ to hydrocarbons $\left(R_{f} 0.85-1.0\right)$, ketones and methyl esters $\left(R_{f} 0.50-0.85\right)$, alcohols $\left(R_{f} 0.15-0.50\right)$ and polar compounds $\left(R_{f} 0.0-0.15\right)$. All TLC fractions were collected from the $\mathrm{SiO}_{2}$ gel by elution with $\mathrm{CH}_{2} \mathrm{Cl}_{2}$. As a control (blank extractions), the entire analytical sequence (except for GC-MS) was carried out under identical conditions except that no sample was present during the initial extraction.

Pipe dope (Bestolife, $0.5 \mathrm{~g}$ ) was extracted ultrasonically with $\mathrm{CH}_{2} \mathrm{Cl}_{2} / \mathrm{MeOH}(1 / 1 ; 50 \mathrm{ml})$. The yellow, fluorescent total extract was separated by TLC $\left(\mathrm{SiO}_{2}\right.$ gel G; hexane $\left./ \mathrm{CH}_{2} \mathrm{Cl}_{2} ; 95 / 5\right)$ into four fractions-equivalent in $R_{f}$ to alkane/alkene $\left(R_{f} 0.9-1.0\right)$, aromatic $\left(R_{f}\right.$ $0.35-0.9)$, metalloporphyrin $\left(R_{f} 0.2-0.35\right)$, and polar $\left(R_{f} 0.0-0.2\right)$ type fractions. The alkane/alkene and aromatic fractions were examined by GC.

\section{Lipid Analysis}

Gas chromatographic analysis of each fraction (including the experimental blanks and pipe dope) was carried out on a Carlo Erba FV2151 equipped with SL490 splitless injector under the following operating conditions: An $18 \mathrm{~m} \times 0.25 \mathrm{~mm}$ SE- 52 wall-coated, glass capillary column was programmed from $50^{\circ}$ to $275^{\circ} \mathrm{C}$ at $4^{\circ} \mathrm{C} \mathrm{min}{ }^{-1}$, after splitless injection at ambient temperature. He carrier or the carrier gas $\left(1.0 \mathrm{Kgcm}^{-2}\right)$ was used. The C-GC-MS system, a Finnigan 4000 with INCOS 2300 data system, is described in full elsewhere (Brassell, Gowar, et al., in press).
Table 1. Sample descriptions.

\begin{tabular}{lclll}
\hline $\begin{array}{c}\text { Samples } \\
\text { (intervals in } \mathrm{cm})\end{array}$ & $\begin{array}{c}\text { Sub-bottom Depth } \\
(\mathrm{m})\end{array}$ & Age $^{\mathrm{a}}$ & M.Y. ${ }^{\mathrm{a}}$ & Lithology $^{\mathrm{a}}$ \\
\hline $\begin{array}{l}447 \mathrm{~A}-10-2,104-120 \\
448-1-1,70-85\end{array}$ & 87.6 & $\begin{array}{l}\text { Middle Oligocene } \\
\text { Middle Miocene }\end{array}$ & $\begin{array}{l}\text { ca. } 30 \\
\text { ca. } 11\end{array}$ & $\begin{array}{l}\text { Vitric tuff } \\
\text { Nannofossil ooze }\end{array}$ \\
\hline $\begin{array}{l}\text { a See site reports, this volume. } \\
\text { b Core highly disturbed during drilling. }\end{array}$ & & & \\
\end{tabular}

\section{RESULTS}

Both core samples yielded colorless extracts. Through C-GC-MS analyses of the "hydrocarbon" fractions, we identified the major components as phthalates from their mass spectra and by mass fragmentography (MF) of m/e 149 (Eglinton et al., 1975). For Section 448-1-1 MF of m/e 191 revealed series of "extended" diterpanes (Crisp et al., 1979; Brassell, $1980)$ and $17 \alpha \mathrm{H}, 21 \beta \mathrm{H}$-hopanes. GC analysis of this sample showed that it also possessed a prominent unresolved complex mixture (UCM) of alkanes. In addition to these compounds, minor amounts of other components were also present in the "hydrocarbon" and other TLC fractions. In each instance, these lipids were also found in comparable concentrations in the "blank" analyses conducted in parallel; GC and C-GC-MS analysis of the alkane/alkene fraction of pipe dope revealed: (1) a prominent UCM maximizing at circa $n-C_{25}$; (2) a complex mixture of $\mathrm{C}_{27}$ to $\mathrm{C}_{29}$ diasteranes and steranes dominated by the $\mathrm{C}_{29}$ components ( $\mathrm{MF}$ of $\mathrm{m} / \mathrm{e} 217$ ); and (3) series of "extended" diterpanes $\left(\mathrm{C}_{20} \mathrm{H}_{36}\right.$ to $\left.\mathrm{C}_{28} \mathrm{H}_{52}\right)$ and $17 \alpha \mathrm{H}, 21 \beta \mathrm{H}$-hopanes $\left(\mathrm{C}_{27}\right.$ and $\mathrm{C}_{29}$ to $\mathrm{C}_{35}$ members). The $\mathrm{C}_{31}$ to $\mathrm{C}_{35} 17 \alpha \mathrm{H}, 21 \beta \mathrm{H}$-hopanes were present as $22 \mathrm{R}$ and $22 \mathrm{~S}$ diastereoisomers with $22 \mathrm{~S} / 22 \mathrm{R}$ ratio of 1.2 for $17 \alpha \mathrm{H}, 21 \beta \mathrm{H}$-homohopanes.

\section{DISCUSSION}

The phthalates found in both samples may be attributed to plasticizers, possibly derived from plastic sample bags. "Extended" diterpanes and $17 \alpha \mathrm{H}, 21 \beta \mathrm{H}$ hopanes are typical of mature ancient sediments, crude 
oils, and sediments polluted with fossil-fuel hydrocarbons (Crisp et al., 1979; Dastillung and Albrecht, 1976; Brassell and Eglinton, 1980). An unresolved complex mixture (UCM) of alkanes is commonly encountered in GC analysis of polluted sediments (e.g., Brassell and Eglinton, 1980), biodegraded and weathered crude oils (e.g., Walker et al., 1975), and oil or natural gas seeps (e.g., Simoneit and Didyk, 1978). In Section 448-1-1, however, the series of terpanes and UCM of alkanes closely resemble those of pipe dope, suggesting that they originate from this drilling lubricant. A comparison of the intensities of the MF of m/e 191 for Section 448-1-1 and pipe dope shows that the contamination is equivalent to an input of $2.1 \mathrm{mg}$ of pipe dope to the $15-\mathrm{cm}$ section of quarter core investigated in this work. In contrast, the absence of such characteristics of pipedope contamination in Section 447A-10-2 shows that the content of this lubricant to that sample is $<0.1 \mathrm{mg}$.

Two additional, independent facts are pertinent to this discussion. First, the initial cores of each hole tend to contain greater quantities of visible pipe-dope contamination (S. C. Brassell, personal observation during Leg 59). Second, unconsolidated sediments and those of sections highly deformed during drilling are most prone to pipe-dope contamination. Hence organic geochemical data that show the presence of significant pipe-dope contamination in a shallow, disturbed nannofossil ooze and its absence in a deeper vitric tuff correlate with general visual observations that were made during the drilling operations.

Pipe-dope contamination should be most apparent in organically lean samples, but it could also make a significant contribution to the hydrocarbons of immature, organic-rich, deep-sea sediments in which the predominant lipids are functionalized components (Brassell, Comet, et al., in press). For example, in Section 434-23-2 - a highly fractured, disturbed, clayey diatomite recovered during DSDP Leg 56-the majority of hydrocarbons may be attributed to pipe-dope contamination, although their concentration is two orders of magnitude lower than the $n$-alkanols (Brassell, 1980). The presence of series of steranes and $17 \alpha \mathrm{H}, 21 \beta \mathrm{H}-$ hopanes in pipe dope is of particular concern because these compounds are frequently reported as constituents of DSDP sediments (e.g., Simoneit, 1978). Fortunately, in the majority of cases, such sediments are lithified; therefore contamination from pipe dope may be partially removed by careful sampling. Results are clearly ambiguous, however, when the hydrocarbon distributions of a mature DSDP sediment and of pipe dope resemble one another (Thomson et al., in press). GC analyses of contaminants (Doran and Johnson, 1979) cannot resolve such ambiguity; C-GC-MS is required but it may still leave questions unanswered.

Of the numerous deep-sea sediments from DSDP and other sources analyzed in our laboratory over recent years, the only sample similarly devoid of significant extractable lipids was a mid-Eocene nannofossil chalk from the continental slope of the Bay of Biscay (DSDP Sample 48-401-5, 1-5; Barnes et al., 1979). These results demonstrate that investigation of the extractable lipids or organically lean deep-sea sediments-such as nannofossil oozes and chalks obtained by DSDP drilling operations-is currently outside the capability of organic geochemical techniques.

\section{CONCLUSIONS}

Analysis of the extractable lipids of two Leg 59 samples and Bestolife pipe dope (drilling lubricant) by GC and C-GC-MS techniques has shown:

1) No significant ( $>0.1 \mathrm{ng} / \mathrm{g}$ dry-weight sediment) lipid components other than extraneous phthalate plasticizers and pipe-dope hydrocarbon contaminants are present in the core samples.

2) The hydrocarbons of the pipe dope include a complex suite of diasteranes and steranes and a series of $17 \alpha \mathrm{H}, 21 \mathrm{BH}$-hopanes.

\section{ACKNOWLEDGMENTS}

We gratefully acknowledge the Natural Environment Research Council for financial support (GR3/2951 and GR3/3758) and a Studentship (SCB). We thank Mrs. A. P. Gowar for assistance with C-GC-MS analyses.

\section{REFERENCES}

Barnes, P. J., Brassell, S. C., Comet, P., et al., 1979. Preliminary lipid analyses of Core Sections 18,24 , and 30 from Hole 402A. In Montadert, L., Roberts, D. G. et al., Init. Repts. DSDP, 48: Washington (U.S. Govt. Printing Office), 965-976.

Brassell, S. C., 1980. The lipids of deep-sea sediments: their origin fate in the Japan Trench [Ph.D. thesis]. University of Bristol, England.

Brassell, S. C., and Eglinton, G., 1980. Environmental chemistry - an interdisciplinary subject. Natural and pollutant organic compounds in contemporary aquatic environments. In Albaiges, J. (Ed.), Analytical Techniques in Environmental Chemistry: Oxford (Pergamon Press), pp. 1-22.

Brassell, S. C., Comet, P. A., Eglinton, G., et al., in press. Preliminary lipid analysis of Sections 440A-7-6, 440B-3-5, 440B-8-4, 440B-68-2, and 436-11-4 from DSDP Legs 56 and 57. In Scientific Party, Init. Repts. DSDP, 56, 57, Pt. 2: Washington (U.S. Govt. Printing Office).

Brassell, S. C., Gowar, A. P., Eglinton, G., in press. Computerised gas chromatography-mass spectrometry in analyses of sediments from the Deep Sea Drilling Project. In Douglas, A. G., and Maxwell, J. R. (Eds.), Advances in Organic Geochemistry 1979: Oxford (Pergamon Press).

Crisp, P. T., Brenner, S., Venkatesan, M. I., et al., 1979. Organic chemical characterization of sediment-trap particulates from San Nicolas, Santa Barbara, Santa Monica and San Pedro Basins, California. Geochim. Cosmochim. Acta, 43:1791-1801.

Dastillung, M., and Albrecht, P., 1976. Molecular test for oil polution in surface sediments. Mar. Pollution Bull., 7:13-15.

Doran, T., and Johnson, P. G., 1979. Examination of potential geochemical contaminants in Leg 48 material. In Montadert, L., Roberts, D. G., et al., Init. Repts. DSDP, 48: Washington (U.S. Govt. Printing Office), 1157-1160.

Eglinton, G., Simoneit, B. R. T., Zoro, J. A., 1975. The recognition of organic pollutants in aquatic sediments. Proc. Roy. Soc. London, $B, 189: 415-442$.

Simoneit, B. R. T., 1978. The organic chemistry of marine sediments. In Riley, J. P., and Chester, R. (Eds.), Chemical Oceanography (Vol. 7): London (Academic Press), 233-311.

Simoneit, B. R. T., and Didyk, B. M., 1978. Organic geochemistry of a Chilean paraffin dirt. Chem. Geol., 23:21-40.

Thomson, I. D., Brassell, S. C., Comet, P. A., et al., in press. Preliminary lipid analyses of Cores 49, 54, and 59 from Hole 462. In Larson, R. L., Schlanger, S., et al., Init. Repts. DSDP, 61: Washington (U.S. Govt. Printing Office).

Walker, J. D., Colwell, R. R., and Petrakis, L., 1975. Microbial petroleum degradation: application of computerized mass spectrometry. Can. J. Microbiol., 21:1760-1767. 